\title{
NOTAS PARA UM ROMANCE
}

José Sérgio Custódio ${ }^{1}$

I

Ontem, caminhei por horas pelo parque. O verde me faz bem. Cheiro de terra. As idéias fluem como que alimentadas por essa pequena liberdade. Em meu cérebro as palavras então dão cambalhotas e formam poemas que não escrevo. E tudo parece um filme. $\mathrm{O}$ vento acaricia meu áspero rosto. Pessoas passam apressadas. Rápidas, fatais. Olho as notícias penduradas nas bancas de jornal. Ana então aparece. Vinha do fundo do tempo. Meus olhos banham-se em lágrimas. Um sentimento ancestral assalta-me o espírito. É a visão de um espectro. Possivelmente uma outra realidade, da qual tomei parte, mas que se fez sem mim. As longas reuniões furavam a noite, adensavam-se em debates, idéias, risos... O apartamento estava sempre povoado. Pessoas discutindo livros, pensamentos, a vida. A madrugada raia irreal. Tenho medo, de suas tonalidades, do que ela me sugere. Vibra no ar uma lufada de vento e sons soturnos suspiradas mágoas rebrilham em meu peito, tenho medo das coisas que não fiz, das coisas que posso fazer. Quero gritar um grande grito, mas o silêncio é minha palavra. O espaço branco irreal, enigmático da folha. Decifra-me ou te devoro. Decifra-me ou te devoro. Sanguínea. É esta cicatriz negra cravada no papel. A aurora é uma espiral endoidecida. Abro os olhos como a aurora abre a vida. Os papéis estão espalhados no meio do redemoinho. A TV está ligada solitária repetindo incessantemente as mesmas notícias da noite. Garrafas vazias amontoam-se sobre o sofá, brotam do chão, desde quando? Não sei. Sei apenas que é um filme ruim, e estou preso nele. Como as horas de um longo pesadelo. A vida não nasce de si mesma, ela nasce de nós, do que fazemos ou daquilo que poderíamos ter feito.

II

A discussão encaminhou-se desalentada. Desconexa. Fragmentária. Pedaços de nós mesmos, soltos em palavras no ar. "Por que as pessoas não se entendem?" perguntou

\footnotetext{
${ }^{1}$ Mestrando em Literatura Brasileira pela Universidade Estadual de Londrina.
} 
Ana, num tom meio despreocupado, a voz mansa como um pedido de perdão. Não houve resposta. Suas palavras vibraram em cada um, no mutismo de todos. "Talvez, seja este o caminho das coisas, não se entender é o modo subterrâneo, irracional de a vida ser mais forte do que nossa compreensão. O não sentido é o seu sentido. Nela cabem todas as respostas e todas as perguntas, é possivelmente este o mistério do homem, seu temor e fascínio." As estrelas continuavam a brilhar. O amor que sinto por Ana, é uma coisa que não cabe em meu peito. $\mathrm{O}$ vento balança suavemente a cortina. Saio para caminhar. Desço só do apartamento. A rua está deserta como minha alma. Atravesso a calçada com um sentimento de liberdade inigualável. Vem a minha garganta uma náusea. A vastidão da vida me desconcerta. Sou talvez um personagem que representa seu papel. Ninguém foge ao seu destino. $\mathrm{O}$ meu é este o da incerteza. Olho a vaga que arremete com fúria sobre a praia. As ondas são eternas. Possuem uma delicada força. É como um braço que acaricia cabelos ao vento. Respiro fundo o gosto da maresia. O cheiro do mar. Meus pés estão na areia molhada. O não sentido da vida é possivelmente o meu sentido. Talvez tudo seja um equivoco.

\section{III}

As luzes povoam a cidade. A rua está deserta. Caminho pela avenida alucinante. Girassóis saem de meu bolso. Meus olhos são caleidoscópios que uivam. As coisas precisam ser ditas, mas eu não sei. Atravesso o bosque verde azulado. Penetro nos meandros da noite. Não, não sei por que as pessoas não se entendem. Este bosque é ancestral. Onda da vaguidão. As folhas sussurram sua mensagem. Ele andava pela cidade. A cidade andava por ele. A sua história é esta. Alguém que busca uma resposta. Talvez, não haja resposta. Ou talvez várias respostas. Não sei por que ele quer contar sua vida. Não estive hoje em casa. Há dias não estou em casa. Não sei como ele entrou em meu apartamento. Sou apenas um simples professor de literatura. E vou assassiná-lo. Perguntei ao porteiro se alguém me procurou, ele disse que não. E as garrafas vazias espalhadas por todos os cômodos? Não sei seu rosto. Apenas sei que veio aqui. E escreveu as linhas de cima. Chove azul do céu. Lírios invadem meus pensamentos como colinas nevadas. Cães verdes ladram no fundo do bosque. Onde esta Ana? A noite de 
setembro afaga minha alma. Reeencontro-a. Ela vem até mim. Seu corpo é doce como esta noite. Minhas mãos percorrem seu universo. Tateiam no escuro sua alma. Alameda de caminhos. Deslizo-me por suas coxas. Quente-úmido. Néctar que me reergue em potência.Calidamente.

As coisas estão amontoadas, desço ao porão. Caixas e mais caixas compõem este espaço do esquecimento. Por que estão aqui? São livros, fotos recortes... fragmentos de mim mesmo. Ele não sabe de todas estas coisas que vejo. Eu sei que sou uma invenção. Nada mais elementar em minha vida do que estas palavras que me tornam carne e osso em seu corpo de memórias. Ao redor tudo é silêncio. Trovões. Ouço agora trovões. É como um êxtase em sentido cego. Esgarçam-se como gaivotas afogadas. Esta história é a minha história, não é a dele. Relógios disparam pela rua. As palavras saem trôpegas como meus sentidos de porão. As horas esmaecem na pia. Guarda chuvas reluzentes brilham como páginas impressas. Sou eu. Isto sou eu. E mais aquilo. E o oposto disso. Nada é o espaço deste agora.

Ela disse-me que as coisas são assim. O vinho acabou. Olho para ela e sorrio. O apartamento anda repleto de vozes por estas noites iluminadas. Falamos, falamos e tudo fica nisso. Acaso poderíamos chegar a algum lugar? "A imperfeição, além da morte é a nossa outra certeza" balbuciou Pedro na sua voz enjoada. "Devemos buscar sermos melhores do que somos" arrematou olhando o relógio. "Francamente, isto parece-me mais um clichê estúpido" disse Antônio como em desafogo "estúpido mais válido"completou Pedro. "Ora, que merda de filosofia é esta Clara falou em voz de fogo, que somos imperfeitos, estou de saco cheio de saber, mas se fôssemos perfeitos não seríamos humanos" e eu não tô nem aí pra tal da porra da perfeição, ser perfeito é como enfiar um dedo do cu, não tem graça, eu quero mesmo é a imperfeição de um pinto dentro de mim. Ecoaram risos pelas sombras.

Não sei o que acontece nestas noites. Tudo parece ganhar uma verdade imaterial. As horas são estas nuvens que caminham. Folhas se acariciam na brisa noturna. Ele escreve isto e está perdido. Habita aqui sorrateiramente. O que ele quer? É apenas um personagem, e sua obrigação, não é indagar os rumos da história. Deve apenar seguir 


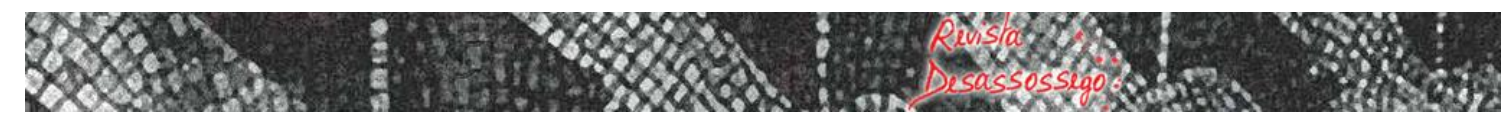

para onde as palavras o levam. Seguir apenas. Isto é um caminho, pode ser o seu caminho. Eu sou o criador e ele é o ser criado. Horas verdes assentam-se sobre o trapézio, girafas circulares discorrem sobre Foucault olhares triangulares se desdizem como beija flores cinzentos uma música abandonada ressoa magneticamente em dias lúcidos e abissais. Para que escreve isto? Para que escreve isto? Beber o branco do papel nas tatuagens impressas. Voltei. O palco ilumina-se. Era ontem. Estou aqui sentado (desde quando?). O tempo se amontoa pela estante e escorre glacial como um beijo. Amo Ana. Ela me entende. Não precisamos de palavras. As palavras criam confusões. A neutralidade do silêncio. A verdade do silêncio. Vou vomitar. É está náusea de tudo. Tudo é turvo. E nunca mais.

\section{IV}

Jogo xadrez no caos dentro de um quadro de Di Chirico. Beijos geométricos se desfazem como as areias vermelhas. O movimento é um diálogo oblíquo. Te ver nua foi como ver o céu sem nuvens com a sua força de azul a devastar as reticências. Aqueles cavalos alados cavalgaram por vertigens e incongruências de mim mesmo. No peito da noite chove. Chove terrivelmente. A chuva é fina e veludosa sob a luz do poste que estou olhando. O tempo é líquido como a chuva que escorre por meu corpo. O barulho da chuva tem gosto de almíscar. O telefone está tocando. Está tocando desesperadamente há três dias. O som vem de dentro de uma maçã sonâmbula. O quarto é este espaço dissonante. Sua névoa é densa como um sonho, caminhos desconexos como luas de nunca e seus olhos de arco-íris. Trilhar a realidade é ir além da realidade. Atendo o telefone, espaço de silêncio branco e ouço delicadamente a declamação de um poema:

A

um

poema

declamação de

declamação

um

poema

poema: 


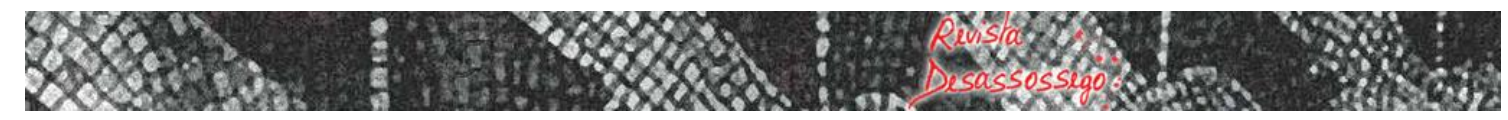

"Pássaros de cobre voam vulcão em erupção mar de veludo canto de violinos emplumados e sereias líquidas amanhecem a aurora de perfumes delicados no sussurro sibilante de tua leve pelúcia geométrica". Silêncio escuro.

V

Sons e fúrias e nuances líricas. Helicópteros no céu de néon fazem circunvoluções lúcidas. Qual o gosto de uma palavra? Ana te vejo, e te desejo na cor verde de teus olhos. O vento sopra alucinadamente. Errantes caminhos de um corpo, de um dia, de um sorriso. De palavras se compõem uma história. De palavras se pode fazer um caminho. Horas dissolutas revolvem dias e noites no espaço de sentimentos inconclusos e talvez por isso mesmo infindos. A vida não se explica a si mesma. Elaboram-se raízes subterrâneas para entender seu mais profundo sumo. Mergulha-se nas correntes marítimas no desconhecido dos olhares de todos os caminhos. Compor as coisas, tão forte e pequenas coisas de matizes densos e reconhecer-se no azul de tardes insones. Hoje é o meu primeiro dia. Quero-o inteiro em seu desperdício de instantes que espocam rubros e laceram-me como nítidas tempestades de areia. Escoam os segundos urdindo sua frágil tessitura de tempo e palavra. As garrafas voam pelo espaço da sala leões rugem esfinges de nenúfares fazem ronda nos jardins de dentro como percepções do acontecido num sonho de intensa realidade; tão real que se parece ficção. As folhas de outono compõem poemas nítidos como girassóis despedaçados. No poema entendo palavras que me dizem mais do que significam, palavras que me afagam o cabelo numa tarde dourada. Sei de todas as formas de desatino e compreendo o êxtase que propiciam. Do crepúsculo jorram amplas auroras do inexplicável. Nas sendas das nuvens vejo veredas: Por acaso o poema precisa de explicação? Por acaso o fato de ser inexplicável não é a sua mais completa explicação? 